\title{
Namus ve Toplumsal Cinsiyet
}

\author{
Namus* and Gender
}

\begin{abstract}
Ayşe KALAV **
Özet: Namus kavramının ele alınacağı bu makalede, öncelikle namus ve toplumsal cinsiyet ilişkisi açıklanmaya çalışlacaktır. "Namus" olgusu, ataerkil sistemin ürettiği bir kavram olan toplumsal cinsiyet örüntüleriyle anlam bulmuş ve gün yüzüne çıkmıştır. Ataerkil düzenin normlarına tabi tutulmuş kadın ve erkek, namus olgusunu nasıl deneyimliyor? Toplumsal cinsiyet, bireylerin davranışlarını düzenleyerek namus ile ilintili farklı yaşantılar mı ortaya çıkarıyor? Literatür incelemesine dayalı olarak hazırlanan çalışma bu sorulara cevap aramanın yanı sıra inşa edilmiş bir olgu olarak namusun, kadın ve erkeğin ayrı ayrı yaşaması zorunlu kılınmış bir pratik olduğu iddiasına dayanmaktadır. Makalede ayrıca namus kavramının tarihsel olarak ortaya çıkışı ve geçirdiği değişimler tartışılmaktadır. Değişen ve dönüşen yönleriyle namus kavramının özellikle neden kadınlar üzerinden tanımlandığı sosyo-kültürel bağlamda çözümlenmeye çalışılmaktadır.
\end{abstract}

Anahtar Sözcükler: Kadın, toplumsal cinsiyet, ataerki, namus, iktidar

Abstract: In this study which discusses the issue of "honor", primarily the relationship between honor and gender is explored. The notion of namus finds its meaning and is revealed through gender patterns which are constructed by the patriarchal system. How do men and women who are subjected to the norms of the patriarchal system experience in this notion? Does gender cause new types of lives associated with honor through controlling the individuals' attitudes? This study, based upon a literature review seeks an answer to this question and furthermore, it asserts the claim that the practice of honor necessitates men and women to experiencing it differently. Further, the history of honor and the changes it has undergone are discussed in this study. This article aims to analyze on a socio-cultural basis why honor is defined the way it is, particularly in regard to women.

Keywords: woman, gender, patriarchy, honor, namus, power

Bireyin toplumdaki yerini belirleyip sosyal statüsüne anlam yükleyen cinsiyet ve toplumsal cinsiyet kavramları, bireyin davranışını şekillendirmektedir. Bu nedenle, birbiriyle iç içe olan bu iki kavram arasındaki farkları ayrıştırmak oldukça önem taşımaktadır. İnsanın doğuştan getirdiği fiziksel, biyolojik ve genetik özelliklerini ifade eden cinsiyet (sex) sözcüğü bir yanda, bireyin toplumda yaşadığı sosyalizasyon süreci boyunca edindiği özelliklerini bildiren toplumsal cinsiyet (gender) sözcüğü diğer taraftadır. Robert Stoller’ın Sex and Gender kitabında belirttiği gibi "Cinsiyet, biyolojik olmaktan çok ruhbilimsel ya da kültürel anlam taşıyan bir terimdir” (Millett, 1987, 55). Kadın ve erkeğin biyolojik cinsiyetine uygun görülen özellikleriyle bu anlamlandırma, bireyi sarmalamaya doğduğu andan itibaren başlar. Kadını ve erkeği, karşı uçlarda tutan özellikleri doğuştan getirdiği özellikler değildir. Bunu en güzel Simone de

\footnotetext{
* I use the Turkish word "namus" as there is no exact English equivalent to it. However; "sexual honour" can be proposed as an approximate translation of it.

** Arş. Gör., Akdeniz Üniversitesi, Kadın Çalışmaları ve Toplumsal Cinsiyet ABD, Antalya, aysekalav@gmail.com
} 
Beauvoir'in 'Kadın doğulmaz, kadın olunur' (Beauvoir, 1993) sözü açıklar. Biyolojik indirgemeci bir anlayışla kadın ve erkeğin doğası gereği davranışlarını temellendirmeye isyan eden toplumsal cinsiyet kuramcıları, bunun kadına ve erkeğe toplumun ayrı öğretiler halinde sunmasının, 'ataerkil düzen'den kaynaklandığını iddia ederler. Akal'ın (1994) Siyasi İktidarın Cinsiyeti'nde ifade ettiği gibi, iki cinsin farklılığı ancak sosyal bir düzenekte anlam bulabilir. Doğanın cinslere verdiği ayrım kültürden kültüre farklı anlamlar kazanarak okunsa da, 'erkek ve dişiyi farklı biçimde birleştiren kültürel yapılar ve toplumsal örgütlenmeler icat etse'de, evrensel olarak kadın ve erkek arasındaki ayrım meşru görülür (Agacinski, 1998, 19).

Ann Oakley, 1970'lerde toplumsal cinsiyet kavramını ortaya atmadan önce (Tahincioğlu, 2011, 31), 'cinsiyet rolü, erkek rolü, kadın rolü’ gibi terimler 1940’larda dahi kullanılmaktaydı (Connell, 1998, 56). Yeni doğan bebek doğduğu andan itibaren toplumsal cinsiyet gerçekleriyle karşılaşır ve bu rolleri içselleştirerek öğrenmeye ve uygulamaya başlar. Stoller gibi kimi araştırmacılar kadınlık ve erkeklik deneyimlerinin temellerini, bu rollerle tanışılan ilk yıllarda arasa da (ayrıca bk. Connell, 1998, 258), medya, okul, sokak, devlet yaşanılan çağa ve yere göre toplumsal cinsiyet sarmalını büyüterek, öğretilerini uygulatmaya devam eder.

Tutum ve davranışlarda kadın ve erkeğin farklı özellikler sergilemesine neden olan toplumsallaşma sonucunda kavramlara yüklenen anlamlarda değişiklikler meydana gelir. Kadın ve erkeğin yaptığı aynı davranış ya da gösterdiği her tutum, toplumda farklı tepkilere neden olur. Artık sadece ataerkil düzenle bireyler arasındaki ilişkilerin düzenlendiği bir sistemden söz etmek yerine, kadın ve erkeği bu düzene oturtan kavramı 'ataerkilliği' ve anlamını sorgulamamız gerekmektedir; çünkü 'ataerkilliğin yeniden üremesi artık sadece aile ile devlet arasında kurulan bir olgu’ değildir (Koğacıoğlu, 2007, 15). Ataerkil düzenle kenetlenmiş toplumsal ilişkiler örüntüsü, kadını ve erkeği farklı davranışlara iten ve tabi tutan namus kavramını işte bu anlamda her gün yeniden üretmektedir. Bu bağlamda namus ve toplumsal cinsiyet ilişkisini yakından incelemek önem taşımaktadır.

\section{a) Namus ve Toplumsal Cinsiyet}

Kültürden kültüre farklılık göstererek farklı isimler taşıyan namus kavramı, toplumsal cinsiyet örüntüleriyle anlamlanır. Çalışma başında belirtilen cinsiyet ve toplumsal cinsiyet arasındaki ayrım, makalenin içeriğinde cinsellikle bağlantılı genişletilecektir. Namusun cinsel ahlaka ilişkin bir değer olması, cinsiyetler arası hiyerarşik düzlemde kadının aleyhine sonuçlanmıştır (Peristiany, 1966'dan akt.; Tahincioğlu, 2011, 34). Kadın utancıyla cinselliğini gizlemeli, erkekse onun kontrolüne verilmiş kadınların 'namuslu' olma haliyle şereflenmelidir. Kadının yüzünün karası olan, erkeğin elinin kiri olabilmektedir çoğu zaman. Bu gibi durumlarda namus ve toplumsal cinsiyet ilişkisine dikkat etmek gerekmektedir.

Peki namus nedir, insan ne zaman namuslu ya da namussuz olur? Kişinin namuslu ya da namussuz olduğuna kim karar verebilir? Namusluluk ve namussuzluk hangi eksende ilerler? Bu soruların cevabı oldukça karmaşıktır. Makale boyunca cevabı aranacak sorulara, namusun ne olduğuna dair açıklamalarda bulunarak başlamak yerinde olacaktır.

Namus sözcüğü, Arapça nāmūs, Aramice ve Süryanice "nmūs/nūmūsā", Hellence nómos sözlüklerine karşı gelmektedir (Nişanyan, 2009). Türk Dil Kurumu’nun namus sözcüğü için gösterdiği iki anlamdan ilki, namusun "ahlak kurallarına ve toplumsal değerlere bağlı olmak" olduğudur. Bu ilk tanımdaki değerlere bağlılık ifadesinden sonra gelen anlamı ise, namus sözcüğünü “iffet” sözcüğüne eş anlaml göstermektedir. TDK'de iffet sözcüğünün anlamına bakıldığında, sözcüğün "cinsel saflık, temizlik ve sililik” ile tanımlandığı görülür. Namus, sözlükteki ilk anlamının ardından nihayet “dürüstlük ve doğruluk” olarak tanımlanır. (www.tdk. gov.tr, 13 Kasım 2010). Türkçe’ye Arapça’dan geldiği düşünülen namus sözcüğü, peygamberin hayatı üzerine Müslüman geleneklerinde göze çarpmasına rağmen, sözcük Kuran'da açık bir 
biçimde geçmemektedir. Esas anlamı ortaya çıkan yasa demektir. Bu sözcügü̈n daha sonra Cebrail meleğini işaret etmek amacıyla kullanıldığı görülür. İncil'den bir kesitin Arapça çevirisinde, Tevrat için "Yahudilerin Yasası" anlamına gelen Hellence bir ifadeden yararlanıldığı dikkat çekmektedir (Harald, 2012).

Namus sözcüğü etimolojik açıdan incelendiğinde kelimenin geçmişinin iktidar kaynaklı yasa, kural, düzenleme, emir anlamlarıyla sahiplenildiğini görürüz. Namus sözcüğünün, eril bir sözcük olan Hellence’deki “nomos” sözcüğünden geldiği belirtilse de bazı kaynaklar bu sözcüğün Türkçe’ye Arapça ya da Farsça'dan geçtiğini ifade etmektedir. Nomos'un işaret ettiği anlamlar arasında sahiplenmek yer almaktadır. Sözcüğün kökü, yiyecekleri paylaştırmak anlamında "nema"dır. Nema bir erkeğin sahip olduğu ve üzerinde hayvanlarını otlattığı alandır (Pervizad, 2005, 297).

İnsan davranışlarını kontrol edip denetleyen kanun, temel yasa anlamındaki nomos sözcüğü, yukarıdaki açıklamalar ışığında güç ve iktidar anlamlarına gelecek şekilde okunabilmektedir. Hellence nomos sözcüğünün, bir toprak parçasını sahiplenip, onu parçalara ayırma anlamına geldiği iddiası, Carl Schmitt'in The Nomos of the Earth adlı eserinde dile getirilmektedir. Düzen ve uyum arasındaki ilişkide yer alan temel süreci anlatmak için de nomos sözcüğünden yararlanılır. Schmitt (2003, 67-68), nomos ve toprak paylaşımı arasında bir bağlantı olduğu gerçeğinin sofistlerden beri çok belirgin olmadığını ifade eder. Aristoteles'in metinlerindeyse bu ilgi oldukça açiktır. Nomos sözcüğünün toprakla bağlantısının yanında, Giorgio Agamben’in Kutsal Insan eserinde belirttiği üzere şiddet ve adaletle de ilgisi bulunmaktadır. Hellenler'in bia ve dike dedikleri, özde birbirlerinin tam zıttı olan iki ilkenin, yani şiddet ile adaletin skandal bir biçimde bir araya getirilmesi oldukça ilginçtir. Uygulanan şiddet, şiddeti ve mağduru önemsizleştirerek, şiddetin nedenini adil olmak adına meşrulaştırır. Bu minvalde, “namussuz” olduğu gerekçesiyle şiddetin son hali ölümle karşılaşan kadın artık yaşamamaktadır. Kadının ölümünün, toplumda “adalet”i sağladığına inanıldığından, şiddetin (sonrasında ölüm) acımazlığı ve cinsiyetçiliği sorgulanmaz. Çünkü nomos, "en güçlü merci olarak, birbirinin karşıtı olan iki şeyin paradoksal birlikteliğini başarma gücüne sahiptir” (Agamben, 2001, 46). Bu anlamda 'nomos'dan gelme namus sözcüğü bir egemenlik alanı oluşturur ve bu egemenliğin kullanım yetkisini kadını ve cinselliğini kontrol etmek suretiyle erkeğe verir.

Erkeğin, kadın ve bedenini kontrol etme amacına hizmet eden olgu, cinsler arasındaki eşitsizliği tarih boyunca sürdüren ataerkil ideolojidir. Bedenin cinsiyetlendirilerek eril ve dişil bir hal alması sonunda oluşan cinsel farklılıklar, adaletin karşısında konumlanmış; farklılıklar eşitsizliğe çevrilmiştir. Devlet, tıp, psikoloji, “kurumlaşmış din” gibi iktidar aygıtları aracılı̆̆ıyla kadının varlığı, kendinden başkasında sorumluluk ve kontrol alanı haline gelmiştir (Berktay, 2009). Kadın ve erkeğin insanlığın iki ayrı cinsi olması, toplumsal cinsiyet ağlarıyla onları eşitsizliğe götürmüştür. "Farklı ama eşit” söyleminden "farklı da eşit de değil”" söylemine geçildiğinde, kadın ve erkeğin farklılıkları adaletsizliği doğurmuştur. Burada belirtilen eşitsizlik ve adaletsizlikle sarmalanan namus olgusu, kadın ve erkeğin hayatına farklı düzenlemeler getirmiştir. "Dil”, namusun iki cinsçe ayrı yaşanması zorunluluğunu örneklendirmesi bakımından davranışları şekillendirme, günlük pratikleri düzenleme araçlarından biri olarak kabul edilmektedir. Bu minvalde, namus ve dil ilişkisini sorgulamak yerinde olacaktır.

\section{Namus ve Dil}

Namus ve toplumsal ilişkiler düzeyinde bir anlamlandırmaya gitmeden önce, devlet ya da aile gibi bir iktidar aracı olan dil üzerinde düşünmek anlamlı gözükmektedir. Toplumsallaşma sürecinde toplumun diğer kültürel değer ve normları gibi toplumsal cinsiyete ilişkin değer ve normlar da dil aracılığıyla yeni kuşaklara aktarılır. Dil toplumsallaşma sürecini sekteye uğratmadan yenileyen en önemli yaşayan gerçekliktir. Dil ayrıca, namus sözcüğü üzerinden kadın 
bedeninin erkek egemenliği ve gözetiminde olduğunu meşrulaştırır ve normalleştirir. Filmlere, kitaplara, oyunlara konu olan heteroseksist ve cinsiyetçi dil ataerkil namus ideolojisini sağlamlaştırır. Zeki Ökten'in (1977) Çöpçüler Kralı’nda bir karakterine söylettiği gibi “Namus işi bu; avratların işi olmaz”. Eğer namus korunması gereken bir kavramsa, erkek bunu kadını ve bedenini kontrol ederek yapar.

Namus konusunda başka bir örnek Fransız toplumundan verilebilir. Napoleon Banaparte'nin kadın ve erkeği yücelten iki değere işaret etmesi, toplumsal cinsiyet bağlamında değerlendirilmelidir. Ona göre "İnsanları yücelten iki büyük değer vardır: Erkeğin mert, kadının da namuslu olması”. Namusun hayattan daha değerli olması gerektiği, her koşulda korunması lazım gelen büyük bir erdem olduğu kadın cinselliği ekseninde değerlendirilmektedir. Benzer şekilde Türk toplumunun geleneksel bakış açısına sahip kesimi için "namusun iki paralık olması” deyimiyle de namusun ne kadar sorunlu bir alan olduğu anlaşılmaktadır. Bu bağlamda namuslu kadın, evden ancak ya kefeniyle ya da gelinliğiyle çıkar. Kadın evlendiği takdirde, babasının koruyuculuğundan ve baskısından kocasının himayesine geçer; böylece kadın için namuslu olmak hayatından daha değerli kılınmış olur.

Ataerkil kültüre kaynaklık edebilecek dil ile ilgili diğer husus ise atasözleridir. Ataerkil ve cinsiyetçi toplum yapısı içinde namusa ilişkin değer ve normları pekiştirmeye ve yeniden aynı şekilde üretmeye yönelik birkaç atasözü örneği aşağıda sıralanmaktadır:

- Her şey hayat için, hayat da namus için feda edilir.

- Irzın kadrini bilmeyen, dinini bilemez.

- Namussuz yaşamaktansa namusu ile ölmek yeğdir.

- Ad (namus) ayıklanmaz, fakat ark ayıklanır.

- Malınız olmasın da namusunuz olsun.

- Irz insanın kanı pahasıdır.

- Kadını erkek değil ar ve namus bekler.

- Avradı er zapt etmez ar zapt eder.

$\mathrm{Bu}$ atasözleri namusun dil aracılığıyla toplumsal cinsiyete ilişkin önyargıları nasıl sosyal olarak inşa ettiğini gözler önüne sermektedir. Günlük yaşam içerisinde sorgulanmadan kabul edilen bu değerler toplumsallaşma yoluyla kuşaktan kuşağa aktarılmaktadır. Karabaş’a (1999, 383) göre atasözlerimizde "Saçları uzun olduğu için akılları kısa olduğu söylenen (sözde şaka olarak) kadınlara karşıt olarak; saçları kısa olduğu için erkeklerin akıllı olduğuna inanılıyor. Saçın uzun ya da kısa olmasıyla zeka düzeyi arasında kuşkusuz nesnel bir bağ yoktur". "Saçı uzun aklı kısa" deyimiyle "kaz kafalı" deyimleri arasında bir bağ kurulmakta ve her iki deyimde de "bir yandan cinsel yaşamın, bir yandan da o cinsel yaşamla özdeşleştirilen kadının kötülenmesi” ortaya çıkmaktadır (Küçük, 2003, 220).

Cinselliğin evlilik kurumu içinde meşru görüldüğü toplumlarda, kadın cinselliğinin kadın evlendikten sonra görünürlük kazandığı düşüncesi, sadece Türkçe söz ve deyişlerle değil; diğer kültürlerde ve farklı dillerde de yeniden üretilmektedir. İngilizce kadının evlenme yoluyla namuslu hale gelebileceği cinsiyetçi fikri "make an honest woman of somebody" (kadını onurlandırmak) deyişiyle açıkça belirtiliyor. Kadın özellikle hamileyse "rezalet” (burada kadının evlenmeden hamile kalması ve rezillik bağlantısı sorgulanmalıdır) çıkmasın diye erkek kadınla evlenir ve kadının namuslu olması sağlanır (www.thefreedictionary.com/honest, 9 Kasım 2012).

Kadını değerler üzerinden yargılayan bir İngiliz atasözüne göre, utancı olmayan kadın, kafası olmayan boyna ve deliği olmayan bir küfeye benzetilerek onun değer verilmeye ya da evlenmeye layık olmadığı vurgulanmaktadır (A neck without a head, buttocks without a hole and a girl without shame are not worth admiring or marrying-Kafasız bir boyun, deliksiz bir küfe ve arlanması olmayan bir kız, evlenmeye veya hayran olmaya değmez) (Lei, 2006, 90). 
Batı toplumlarında olduğu gibi bir doğu toplumu olan Pakistan’ın kuzeydoğusunda yaşayan etnik paştunlarının kullandığı bir atasözü de, namusu yaşamak pahasına korunması gerekli büyük bir değer olarak nitelendiriyor. Bir Paştu, bu atasözünde kafası için servetini ve namusu için hayatını feda edeceğini iddia etmektedir ("Mal me da Sara Jar Sha aw Sar me da Namus na Jar sha" or "I will sacrifice my wealth for my head and will sacrifice my life for my Namus") (Miakhel, 2009, 3).

Dillerdeki bu cinsiyetçi yapı gösteriyor ki; kadın edilgen, kendi cinselliği ve bedeni üzerinde söz sahibi olmayan, erkeğin denetimine ve himayesine ihtiyaç duyan bir varlıktır. Erkeğin koruyan kadının kollanan olduğu ayrımcı düzenini antropolog Nükhet Sirman, şöyle belirtir: "Bir erkek, kendi sorumluluğu altındaki kadın ya da kadınların cinselliğini kontrol edemezse 'namussuz' olurken, namussuz kadın kendi cinselliği üzerinde kontrolü gerçekleștiremeyendir. Namussuz erkek, sözüne güvenilmeyen, hem kendi cinselliği hem de korumakla yükümlü olduğu kadının cinselliğine söz getirendir" (Sirman, 2006, 49). Sonuç olarak ataerkil yapı içerisinde kadın cinselliğinin erkekler tarafından denetim altında tutulması gerekmektedir.

\section{b) Değișen ve Dönüșen Yönleriyle Namus Kavramı}

Sürekli değiş̧en ve dönüşen dünyada namusa ilişkin değer ve normlar ve buna bağlı olan tutum ve davranışlar da değişmektedir. Özellikle bir duvar olarak tanımlanabilen ve duvar gibi kutsal yönelimler üzerine kurulmuş olan nomos da toprak ve mülkiyet gibi büyüyüp gelişebilir (Schmitt, 2003, 70). Genel bir düzenekte ahlak anlayışı olarak kabul edilen ve günümüze kadar toplumu düzenleme, insan hayatını ve davranışını denetleme işlevi gören namus kavramı, toprak ve mülkiyet sözcükleri üzerinden kadın bedenini işaret edecek şekilde sürekli değişmekte ve dönüşmektedir. Namus kavramının, ortaya çıkış ve oluşum nedeni geleneğe havale edilemeyecek karmaşıklıkta ve durağan olmanın çok ötesinde sürekli devinim halindedir. Bu çalışmada namusun zaman içindeki hareketliliği, toprak, mülkiyet ve akrabalık ilişkileri bağlamında incelenerek, ardından modernizmle beraber namusun evrilerek biyo-iktidar aracı haline gelmesi tartışılacaktır.

\section{Namus ve Toprak İlişkisi}

Özel mülkiyetin ortaya çıkışıyla kadının, erkeğin egemenliğine girdiği fikri, Engels’le başlamış ve sonrasında savunulmaya devam edilmiştir. Bu savunulardan bir tanesi Fransız antropolog Germaine Tillion'a aittir. Namus kavramının, Akdeniz toplumlarında mülkiyet, toprak ve akrabalık ilişkileri dolayımıyla ortaya çıktığı fikri, antropolog Germaine Tillion’ın 1934 yılında Akdeniz toplumlarında yaptığı çalışmaya dayanmaktadır. Türkçe'ye 2005'te Harem ve Kuzenler adıyla çevrilen kitabın önsözünde Nükhet Sirman, Tillion'ın kimliklerin ve toplulukların yapısının toprak ve toprağa el koymayla şekillendiğini iddia ettiğini belirtmektedir.

Akrabalık salt kişiler arasındaki ilişkiler değil, bireylerin kime tabi olduğunu yerel ve gündelik düzeyde de kontrol edip düzenleyen bir denetim mekanizmasıdır. Denetlenen düzenlenmesi gereken toplum ve insan ilişkileri olunca burada bir ahlak düzeneği oluşturmak gerekecektir. Akrabalık sonucu çıkan ahlak kuralları ise, "kan kavramının etrafında hürmet, sevgi, dostluk, düşmanlık, intikam, kıskançlık, korku, güven, sakınma, kaçınma, hizmet etme, emretme ve kollama sözcükleriyle ifade edilir" (Sirman, 2006, 22).

Toplumdaki sosyal ve ahlaki düzeni sağlamakta bir araç olarak kullanılan akrabalar, "evin içi” olarak adlandırılır ve "evin malı” olarak imlenen kadın ve toprağın sahipliğini yapar. Kadın tıpkı toprak gibi yabancıdan korunması gerekli bir düzenekte erkeklerin sahipliğinde temsil bulur. Toprağa ve kana yabancının karışmaması için, “namus" u yani "kadın” ev içinde akrabalar arasında tutmak esastır (Tahincioğlu, 2011, 128). Altından toprağının alınacağı korkusu, namusun da alınabileceğine denk düştüğünden toprak ve namus arasında bir paralellik vardır. 


\section{Namus ve Mülkiyet İliş̧kisi}

Toplum çok başlı evlilikten tek başlı evliliğe doğru yol alınca, kadın ve erkek arasındaki ilişki erkeğin lehine olacak şekilde yeniden düzenlenmiştir. Engels, Ailenin, Özel Mülkiyetin ve Devletin Kökeni kitabında erkeğin mülkiyetinin bu düzenle arttı̆̆ını savunur. Erkek artık beslenme kaynağının, hayvan sürüsünün ve yiyecekleri sağlamasında kullanacağı araçların sahibidir (Engels, 2008, 66). Analık hukukunun zamanla yok olması, aile içinde mutlak otorite olacak erkeğe, kontrolü altındakileri yaşatma ya da öldürme hakkı tanıdı. Evdeki söz hakkını yitiren kadın, erkeğin çocuklarını doğurup onları besleyen biri haline geldi. Kadın, bir tek adama ait olan aile düzeninde "evcil köle" ye dönüștü. Evcil köle anlamına gelen famulus sözcüğünden türeyen familia (aile) erkeğin mülkiyeti altındaki kölelerin tamamı anlamına gelmektedir (Engels, 2008, 69). Haklarından yoksun bırakılan kadının en büyük sorumluluğu, erkeğini doğurduğu çocukların kendi çocuğu olduğuna inandırmasıydı. Bu sorumluluk, kadınların cinselliklerini bağlı bulundukları aile içindeki erkeğe hizmet amaçlı kullanmalarını gerektiriyordu. Çünkü erkek, mirasını bırakacağı çocukların kendi çocukları olduğundan emin olmalıydı. Soyun erkek tarafından belirlendiği ataerkil düzen, kadının eskiden yaşadığı cinsel özgürlüğünü hatırlama olasılığına karşı, kadını daha fazla baskı altında tutmuş ve cezalandırmıştır. Yasal olarak karısı olduğu erkeğe karşı iffetini korumakla yükümlü kadının namusunu korumak da bu nedenle erkeğe kalıyordu.

Kadının namusunu koruma görevi sadece kadının kocasıyla sınırlı değildir; bu sorumluluk alanı anne babasından, yakın akrabalarına ve hatta komşularına kadar uzanabilir. Denetim ve kontrollerle bedeninin kendine ait olmadığı hatırlatılan kadın, egemenliği altındaki erkeklerin yüzünü kara çıkarmamak adına kendini denetler. Örneğin, "bir kızın evlenmeden bekâretini kaybetmesi açıkça ataerkil olan eski dünyada, hem aileyle kızın kendisinde utanç verici bir denetim eksikliği hem de kızın babasına karşı işlenen bir mal suçu oluşturmaktaydı" (Blank, 2008, 199). "Kadın cinselliği üzerindeki toplu denetimin önemli bir nedeni kadının cinsel iffeti ile aile ya da sülalenin şerefi arasında kurulan bağlantıdır. Kadınlara, herhangi bir yanlış davranış nedeniyle bütün bir topluluğa, sülaleye ya da aileye utanç ya da şerefsizlik getirecek denli muazzam olumsuz bir güç atfedilmiştir. Bu nedenle tamamen eve kapatılma ve örtünmelerinden, kamusal alana girişlerinin ve hareketlerinin sınırlandırılmasına kadar varan katı dışsal baskılar altında yaşarlar" (Kandiyoti, 1997, 74). Fatima Mernissi, kadınların baskı altında tutulması ile namus ve bekâret kavramlarına verilen önemin İslamiyet’ten kaynaklandığını ifade eder. Kadının cinselliği aktif olduğundan, kadına cinselliğini Kuran'da belirlenen ölçütler dâhilinde yaşaması emredilir. İslamiyet, cinsel güdülerin varlığını inkar etmez; ancak cinsel güdüler evliliğin müsaadesiyle üremek için gereklidir. Kadının fitne ve kaos yaratan bir varlık olarak görülmesi, kadının toplumda duruşunu edilginleştirir. Cinselliğinden korku duyulan kadının, erkeğin aklını zapt edeceği ve ardından toplumun düzenini bozacağı düşünüldüğünden, kadın namus ya da bekaret gibi kavramlar üzerinden sıkı bir denetim altına girer (Mernissi, 1987). Mernissi'nin Fas'ta ve Hanna Papanek'in Afganistan'da purdah sistemi üzerine yaptığı çalışmalar, kadınların cinselliklerinin örtünme üzerinden nasıl etkisiz hale getirildiğini anlatır (Kandiyoti, 1997, 326). Nevin Yıldız Tahincioğlu'nun 2010 yılında Şanlıurfa'da tamamlamış olduğu doktora çalışmasındaki bir erkek katılımcının görüşleri, kadınlar kapatılmaz ve kontrol altında tutulmazlarsa eğer kadınların toplumun düzenini bozacağına yöneliktir (Tahincioğlu, 2011, 207). 50 yaşındaki Arap kökenli bir erkeğin ifade ettiği düşünce, Mernissi’nin “İslamda Aktif Kadın Cinselliği Anlayışı” makalesinde Müslüman feminist Kasım Amin'den aktardığı fikir ile örtüşmektedir. (Mernissi, 1987, 31). Erkek katılımcının şu sözlerle dile getirdiği görüş erkeğin cinsel dürtülerinin kadınlara göre daha zayıf olduğudur:

"Sen erkeğe sahip çıkmazsın, niye çünkü erkektir. Ona bir şey olmaz, yatar kalkar senin adın olur iki paralık. Yani erkekler öyledir, Allah 
onları öyle yaratmıs, pistirler, kendilerine hakim olamazlar, namussuzdurlar. Ama sen kendi karına kızına sahip çıkacaksın, erkekleri bilirsin, sen serbest bırakırsan hemen atlarlar karına, kızına. Yani ben kendi kızıma güvenmediğimden değil, ben onlara (erkeklere) güvenmediğimden. Yani kendimden biliyorum ha seni tutacak hiçbir şey yoktur, buradan bir kadın geçse sahipsiz, sen dersin o sahipsiz o zaman belki... Bu yüzden dirlik için, düzen için herkes kendi karısına, kızına sahip çıkacak. Çıkmazsa erkekleri kim tutar, sonra gelsin kavga çıksın kan”

(Tahincioğlu, 2011, 206-7).

Kadın ve bedeninin kendisine değil, bağlı bulunduğu aileye ve sonrasında topluma ait olduğu anlayışı, yalnızca gündelik hayattaki uygulamalarla sınırlı değildir. Yazılı kanunlar aracılığıyla, cinsiyetçi fikirlere meşruiyet kazandırılır. Kadın cinselliği (özellikle bekar kadının cinselliği) ailenin itibarına ve namusuna yönelik bir engel ve sürekli bir tehdit olarak görülür. Medeni Kanun ve Türk Ceza Kanunu gibi yasalar son zamanlarda kadının lehine düzenlenmeler içermesine karşın, Türk hukuk sistemi, kadını bir birey olarak görmeyip, ona karşı işlenen suçları bireye karşı değil, aile ve toplumun düzenine karşı işlenen suçlar kapsamında görme eğilimindeydi. 2005 yılında yürürlüğe giren yeni Türk Ceza Kanunu'nda bu egemen erkek bakış açısı değiştirilerek, kadına yönelik cinsel suçlar, aile ve toplum düzenine işlenen suçlar başlığı altından çıkarılmış; bunun yerine kişiye karşı işlenen suçlar başlığına yerleştirilmiştir (Göktürk, 2010). Böylelikle, kadının çıkarlarını göz önüne almadan toplumun ve ailenin selameti için düzenlenmiş uygulamalara yasalar nezdinde son verilmiştir. Eski TCK’nin 440. maddesinde zinayı kadın ve erkek için farklı şekilde suç kabul eden anlayış, cinslerin eşitliği gözetilerek yeniden düzenlenmiştir. Kadının evlilik dışı bir kez cinsel ilişkide bulunmasını zina için yeterli gören yasa, erkeğin bu ilişkiyi sürekli olarak "karı-koca" ilişsisi düzeyinde yaşamasını zina olarak değerlendirmekteydi. Benzer cinsiyetçi yaklaşım tecavüze karşı veril(mey)en cezada da belirgindir. Tecavüzü gerçekleştiren kişi, kadınla evlendiği takdirde cezasından kurtulabilmekte; kadının namusu da aile ve toplumun çıkarları gözetilerek korunmuş olmaktaydı (Decker, 1998, 332). Bunlara ilave olarak evli ve evli olmayan kadınlara karşı işlenen suçlarının cezasında da bir ayrımcılık söz konusu idi. Evli ve aile içinde olan kadına değer atfeden ataerkil sistem, evli kadının kaçırılmasında yedi yıl ceza öngörürken, evli olmayan kadının kaçırılmasında üç yılla yetinmektedir (Özyeğin, 2009, 111). Bu uygulamayı kadın evlenip aile içinde kocasının egemenliğinde çocuk doğurur hale geldiğinde kutsallaşıp, değer kazanıyor şeklinde yorumlamak mümkün gözükmektedir. Sistem kadının mağduriyetini değil, kadının mülkiyetini elinde bulunduran erkeğin "mal”"ına gelen zararın onda yarattığı sıkıntıyı azaltmayı önemsemektedir. Adeta, kadının "sahipleri” arttıkça ona yöneltilen suçlar daha ağır cezalandırılmaktadır.

\section{Namus ve Biyoiktidar}

Üzerinde antropolojik çalışmalar yapılan namus olgusu, günümüze dek mülkiyet ve erkek soyu üzerinden ilişkilerle tanımlanmıştır. Bir soyun saf bir biçimde devamlılığını sağlamak arzusu, kadının doğurganlık yetisi üzerinden, soy tarafından denetlenirken bu denetim zamanla ulusun saflığını tedarik etme amacıyla devletin kontrolüne geçmiştir (King, 2008, 318).

Sözcüğün etimolojik anlamı, zamanla farklı anlamlara gelecek şekilde uygulama alanları bulmuştur. Namusun akrabalık ilişkileriyle sarıldığı tezini savunanlara göre, (Sirman, 2006; Tillion, 2006) namus hem birey üzerinden tüm grubun kimliği hem de toplumsal ilişkilerde içselleştirdiği bir davranış biçimi olmaktadır (Mutluer, 2008, 21). Toplumun kadına özgü erdemler diye sunduğu her şey, kadını yapay bir farklılık alanına hapseder (Akal, 1994, 93). Bu nedenlerdendir ki namus, kadın cinselliğini toplumun kadınlara yüklediği anlamlar dahilinde sınırlı bir biçimde yaşama tutsaklığıdır. Kadının giydiği kıyafet, dışarı çıktığı saat, kimle nereye 
gittiği, evli olup olmadığıyla ilgili maruz kaldığı cinsiyetçi ifadeler, kadının toplumun ortaya koyduğu kurallar çerçevesinde yaşamasını zorunlu kılar. Çünkü kadının yaptığı herhangi bir hareket erkeğin onurunu yitirmesine neden olabilir. Örneğin, İran'da kadınların tesettürsüz dışarı çıkmaları ve dolaşmaları erkeklerin namusuna zarar verebilir (Mojab, \& Abdo, 2006). Burunlarına zarar gelecek korkusuyla hareketlerine dikkat etmesi gerektiği öğretilen Pakistanlı kadınlar da, kendilerine tanınmış alan içerisinde belirli kurallara göre hareket ederler. Pakistan’da kadınlara 'Burnuna dikkat et' diyerek öğüt verilmesi, burnun onur ve şeref sembolü olması ile ilgilidir (http://www.bianet.org/bianet/kadin/140124-allaya-32-yil-sonra-burun-ameliyati, 6 Kasım 2012). Bu nedenle, kadının herhangi bir namussuzluk yapması durumunda burnu kesilerek cezalandırılır. Hayata dar bir pencereden, ona uygun görüldüğü kadarıyla bakabilen kadın, ona verilen cezaları o kadar içselleştirir ki, ona namusun ne olduğu sorulduğunda cinselliğini kontrol etmek anlamına geldiğini bilir.

Kadın bedeniyle özdeşleşen namus kavramı, biyo-iktidar aracı olarak bedeni disipline edici bir norm olarak görülmektedir; bu da denetleyenin ve düzenleyenin her gün yeniden yapılandırılması anlamına gelir. Cinselliği denetleme gücü iktidarın elinde toplumdan topluma şekillenirken, iktidar anlayışı da zamanla değişir ve bireyler arasında dolaşım serbestliği yakalar. İktidarın 'ahlak' anlayışını benimseyen bireyler, toplumun gönüllü ahlak bekçisi haline gelirler. $\mathrm{Bu}$ da toplumsal cinsiyetin ve toplumsal cinsiyet ağlarını denetlemeyi kendine ilke edinmiş ataerkil iktidar mekanizmasının devamlılığını sağlar (Caner, 2004, 19). Namus, sosyal düzenin bir hiyerarşi içinde sürmesi için cinselliğin hem bireysel hem de toplumsal bağlamda kontrolünü kolaylaştırmaktadır. "Namus da cinsiyetin sınırını çizerken bize iktidarın yasaklarıyla ilgili bilgi de vermiş oluyor” (Mutluer, 2008, 22-23).

Kadın bedeniyle ilişkilendirildiğini iddia ettiğimiz "namus" dolayısıyla cinsellikle sıkı bir bağlantı içindedir ve hiç kuşkusuz devletin de cinsellik adına söyleyeceği çok fazla şeyi vardır. Michel Foucault'un Cinselliğin Tarihi kitabında üzerinde sıkça durduğu üzere, devletin cinsellik hakkındaki konuşmaları, toplumu neyi nasıl nerede yapması ya da yapmaması hakkında yönlendirir, yargılar (Foucault, 1993, 32).

Ataerkilliğe dayalı toplumlarda grubun üremesi bireylerin cinsel davranışına bağlıdır. Dolayısıyla bireysel cinsellik tüm toplumun denetim ve kontrolüne tabi namus olgusuyla şekillenmek zorunda bırakılmıştır. Kişileri gönüllü ahlak bekçiliğine soyunduran itki, Ovidius’un dile getirdiği "Kadının bekçisi namustur" anlayışına paraleldir. Aynı zamanda "yurttaşların her biri de cinselliğin kullanımını denetleme yeteneğine sahip olmalıdır” (Foucault, 1993, 30-35).

Geleneksel bir yapılanmanın ardından, Cumhuriyet rejimiyle beraber modern ulus olma özelliğini kanıtlayan Türkiye'de namus kavramı aile içine sindirilerek canlılık kazanmıştır.

Namusu geleneksel bir değer olarak gören modernistler, namus sözcüğü yerine ahlak-temiz ahlak sözcüğünü koyduklarında, namus kavramının ortadan kalktığını düşünmeye başladılar (Koğacıoğlu, 2007). Halbuki sadece namusun kontrol ediliş tarzı değişmiştir. Aile ve okulda eğitim yoluyla üretilen söylem, devletin iktidar aygıtlarıyla canlandırdığı temiz ahlak üzerine yoğunlaşmıştır. 'Namus artık pamuk ipliğine bağlı değil', ya da 'hemen yalanıp bitecek bir parmak bal değil’. Bu namusun başında bir erkek durarak koruyacă̆ bir şey olmaktan çıktığını gösterir. Namus artık kadının kendi benliğinin bir parçası olan ‘özdeki ahlakın’ koruması altındadır (Tahincioğlu, 2011, 191-192). Kişiye bırakılan namusun korunması fikri, Tahincioğlu'nun saha çalışmasında bir erkeğin ağzından şu şekilde ifade edilmekte:

“Namus kadının içindedir, kimse ona zorla, basklyla, ölümle veremez. Ben inanırım buna, bu yüzden de kızların iyi eğitilip bir ordunun içine bırakılabileceğine inanırım. Yani eğer akıllı ve ahlaklı ise babasına, kocasına karşı sadıksa, sevgi duyuyorsa onun namusa mamusa da 
ihtiyacı kalmaz... Çünkü namus demek bir yerde zor demek, baskı demek... Yani bir yerde kadının içinde olmayan ahlakı kadına zorla dayatmak demek... Ama eğer sen kadını eğitirsen, aklını kullanmayı ögretirsen, yani cahil birakmazsan... O da erkek gibi insandır ve cinselliğiyle değil insan olma vasfıyla her ortama girer... Okur da çalışır da, erkeklerle arkadaşlık da yapar...” (Tahincioğlu, 2011, 192).

Bireyin namus kavramını içselleştirmesinden önce devlet eliyle bir namus kavramı inşa edilmiştir. Devletin modernleşmesi de kadın üzerinden bir söylem üretmiştir. Okuyan, kamusal alana çıkıp erkek yurttaşlarla çalışarak eşit haklara sahip olan 'modern’ görünümlü kadın, ulus devletin inşasında baş etkenlerden olmuştur. Kadının doğurganlık özelliğini kullanarak kadın bedenini milliyetçi söylemlere alet eden yaklaşımlar, namus kavramının kullanım alanının genişlemesine neden olmuştur (Davis, 1997). Devlet baba, anavatan karşıtlığı üzerinden giden erkeği iktidarla, kadını da vatan toprağıyla eşleyen söylem, kadının da vatan toprağı gibi dış saldırılara karşı savunulması gerektiğini ifade eder. Dersim harekatına katılan ilk kadın savaş pilotu Sabiha Gökçen’in kadın olma dolayısıyla yüklendiği görev, namus ve milliyetçilik ilişkisini örneklendirmek açısından oldukça anlamlıdır. Harekat öncesinde, Atatürk, Sabiha Göçken'le aralarında geçen konuşmada Göçken'e bir kadın olduğunu hatırlatır ve namusuna herhangi bir zarar geleceğini hissetmesi durumunda namusunu korumak için ya kendini ya da karşısındakileri öldürmesini öğütler. Bu konuşma daha sonra Göçken'in anılarına "Dersim Harekatı ve Namusumu Koruyacak Silah” adında bir bölümle geçer (Altınay, 2004, 39).

Modern ulus devlet inşasında kadının kamusal alana çıkıp çalışması, savaşması modernleşme ereğinde kadının bir araç olarak kaldığını göstermektedir. Serpil Sancar’ın ifadesiyle bu, 'toplumun modernleşmesine evet; ama ailenin ve kadınların modernleşmesine hayır demek' anlamına gelmiştir (Sancar, 2006, 4). Sirman’a $(2006,55)$ göre, “Cumhuriyet sonrası dönemde namus kavramı kadının başını kapatarak elde edilmesi gereken bir erdemden vazgeçerek, onları okutma yoluyla bireyselleştirir. Namusun bacak arasında değil; kafada aranmasını uygun gören zihniyet, örtünmeyi geleneksellikle, geri kalmışlıkla ilişsilendirmiş, Şemsettin Sami gibi kişiler, kadınların namuslu olmak için örtünmeye gereksinim duymadıklarını bunun yerine mantığın olmasını savunmuştur”. Eğer akrabalık ilişkilerinin üzerine gidip yok olması sağlanabilirse, namus sadece karı koca ilişkisine dayalı ulus devlet inşalarında süreç içerisinde kaybolacaktır. Ancak namus kavramı yok olmamış, kendini yeniden üretmiştir. Cumhuriyet dönemiyle kamusal hayata çıkmaları sağlanan kadınlar, kadın kimliklerini özel alana hapsederek erkek yurttaşların yanında yer almaya başlamışlardır. Ancak onlardan beklenen, modern devletin modern Türk kadınına yüklediği sorumluluklardan birisi olarak aseksüel, namuslu kadın kimliğine uymak zorunluluğudur (Parla, 2001, 74).

Sirman'a (2006, 59) göre namus, "sözde modern aile temelli ulus devletlerinde kadını disipline etmek amacıyla inşa edilmiş, toplumsal cinsiyet temelli bir şiddet türüdür”. Uysal bedenler inşa etme kaygısıyla, modern fakat erdemli, namuslu, iffetli kadınlar yaratma telaşı devletin göz yumduğu bekâret muayeneleri aracılığıyla kurumsallaşmıştır. Devlet kontrollü gerçekleştirilen bekâret muayeneleri, 1999'da kadınların rızasını şart koşan bir genelgeyle değişikliğe uğramış dahi olsa (Parla, 2001, 66) tecavüz gibi bazı durumlarda bekâret muayenesi uygulamasına devam edilmektedir. Bu nedenle bekâret muayenesi konusundaki değişikler ve oluşturduğu etkiler, namusun geçirdiği değişimi göstermek açısından yararlı olacaktır.

Ayşe Parla, cumhuriyet sonrası dönemde, kadın bedenine yönelik şiddet türlerinden biri olarak görülen bekaret muayenelerini Michel Foucault'un düzenleyici ceza (corrective penalty) adını verdiği terimle ilişkilendirmiştir (Parla, 2001, 81). Devlet eliyle kadın bedeninin kontrol edilmesi, dönemin kadın bakanı Işılay Saygın tarafından haklı gerekçeleri olduğu nedeniyle savunulmuştur (Parla, 2001, 67). Toplumun düzeni ve ahlaki yapısı kadın cinselliğinin kontrol 
altında tutulmasıyla sağlanacaktır. Çünkü namus, "topluluk düzeninin kuşaktan kuşağa sorunsuzca aktarılmasının kişi çıkarlarından daha önemli olduğunun bir ifadesidir”' (Sirman, 2005, 22).

Bekaret ve bekarete yüklenen anlamlar dahilinde yapılan tıbbi olmayan sosyo-kültürel bekaret muayeneleri, kadınların cinselliklerini hangi sınırlar içerisinde yaşadığına örnektir. Gül Özyeğin'in 2002-2004 yılları arasında Boğaziçi Üniversitesi öğrencileri arasında yaptığı çalışma, 19-23 yaşları arasındaki 29 kadının bekarete yönelik tutumlarını ölçmeye yöneliktir. Namusun geleneksellikten modernizme terfisi çalışmada öne çıkmaktadır. Kızlık zarının kontrolü ve sorumluluğu aile, akraba, arkadaş ve komşulardan (Kandiyoti, 1997, 73) bireyin sorumluluğuna bırakılmıştır. Böylelikle, kızlık zarı, biyolojik taşıyıcısı olan vajinadan kaydırılıp tüm bedene yerleştiriliyor; bu yolla beden "kızlık zarına dönüştürülüyor” ve kadın olarak adlandırılan beden üretiliyor (Abu-Odeh, 2003, 255). Dışarıdan gelen tepkileri ve uyarıları geleneksellikle ilişkilendiren katılımcılar, cinsellikleri üzerindeki otokontrollerini modern olarak göstermektedir. Bu, bekaretin fiziksel boyutunun ahlaki boyutuyla toplumsallaşması ve genişlemesi olgusu, namusun bacak arasında değil kafada olduğunu savunan söylemler üretmiştir (Özyeğin, 2009, 109). Görünüşte bakire (Virginal Façades ) adını verdiği makalesinde Özyeğin, katılımcıların özellikle annelerine hissettiği suçluluk duygusuyla, “teknik” olarak bakire kaldıklarını ifade etmektedir. Cinselliklerini izin verilen sınırlar içinde yaşayan kadın, her ne kadar namusu geleneksellikle, akrabalıkla anlatsa da, toplumun denetiminden kurtulamamıştır. Kadın artık vajinal kızlık zarını değil, "fiziksel ve toplumsal zar"ını el değmemiş vaziyette muhafaza etmek için çaba gösterir (Abu-Odeh, 2003, 256). Denetimi gerçekleştirenlerin kapsamı sınırlanmış, en önemlisi kişiyi kendi ahlak bekçisi durumuna getirmiştir (Özyeğin, 2009).

Bekaret muayeneleri, geleneksellikten modernizme geçişte namusun kontrolünün farklılaştığını örneklendirmek amacıyla verilmiştir. Bekaret muayeneleri öncesinde ise, daha çok geleneklerle ilişkilendirilebilecek çarşaf asma geleneğinin olduğunu ifade etmekte yarar var. Kadın, evlendiği günün ertesi sabahında evlendiği güne değin cinsel saflığını koruduğunun göstergesi olarak, üzerinde bekaret kanının olduğu kanlı bir çarşafı kaynanasına teslim eder. Evlendikten sonra, erkeğin annesinin ve babasının hareketlerini kısıtlamasına ve denetlemesine maruz kalan kadın, evlendiği günün ertesinde namuslu olduğunu bakire olduğunu kanıtlamak zorundadır. Çarşaf asma geleneği olarak bilinen, kadının cinsel saflı̆̆ının sergilenmesi, Tillion’da (2006, 204) belirttiği üzere Yunanistan’da da kayınvalideler aracılığıyla komşulara duyurulur.

Çarşaf asma geleneğinde olduğu gibi, kadının bekaretini imleyen kanı sergileme arzusu, baskı ve denetlemenin salt devlet ve erkek kaynaklı olmadığını; aynı zamanda kadınlar arası kontrolü göstermesi bakımından da anlamlıdır. Namus, toplumdaki her bireyin bir başkasını denetlemek için kullandığı araçlardan biri olarak şekillenir. Öyle ki, şehirli kadınların erkeklerle sürekli kol kola gezmeleri köylü kadınlar tarafından eleştirilip yargılanmıştır. Benzer ilişki Ali Bedevileri ve Mısırlı köylüler arasında da vardır. Mısırlı bir çiftin aynı odada uyuması ya da sokakta el ele dolaşması, diğer grup tarafından köylü kadınların verdiği tepkiye yakın biçimde ahlaksız olarak görülmüştür. Sirman’ın belirttiği gibi namus “böylelikle, gruplar arası ve grup içi rekabet ilişkilerinin düzenlendiği bir eksen haline gelmektedir” (Sirman, 2006, 50). İktidarın dikey bir düzlemde hareket etmediği, yatay ilişkiler ağıyla toplumdaki her bireyi farklı farklı etkilediği oldukça belirgindir. Bu anlayış, devlet kontrolüyle yapılan bekaret muayenelerinden kadınların diğer kadınları namuslu olma(ma) haline göre gözetlediği günlük pratiklere dek uzanmaktadır.

Sonuç olarak, Cemal Bali Akal'ın belirttiği üzere namusunun kadın cinselliği ile ilintili olduğu zannı, "kadın tabiatı ve cinselliği diye adlandırılan şeyin ayrımcı bir erkek söylemi tarafından yaratıldığının örneğidir. Erkekler siyasi üstünlüklerini ve güçlerini devam ettirebilmek adına, kadının bedenini ve aklını cinsiyetçi bir düşünceyle "yoğurup biçimlendirir". Bu süreçte kadına düşen sosyal rol, farklı ve boyun eğmesi gerekli aşağı bir cins olarak, erkeğin 
onu yerleştirdiği mitik alanda, erkek söylemine, kendisinin olmayan bir bedeni kullanıp cevap vermek olmuştur” (1994, 47). Kadının verdiği yanıtlar, devrimci bir karşı çıkış olmaktan çok uzaktır; aksine Kandiyoti'nin deyimiyle bu, yeni ataerkil pazarlıkları doğurmaktadır. Kadın ve erkeğin toplumsal rolleri gereği verdiği farklı tepkiler, namusun dönüşümünde büyük önem taşımaktadır. Mülkiyet, toprak ve akrabalık sözcükleriyle sarmalanmış namus; milliyetçilik ve modernizm kavramlarıyla yüklü namus anlayıșına süreç içerisinde evrilmiştir. Kolektif namus dayanışması zamanla bireyselleşmiştir. Kadın bedeni ilkin mülkiyet, sonra toprak ve sonuncu ama son derece önemli olan, milliyet ve ulus deyişleriyle bir iktidar mekanizmasına dönüşmüştür. İktidarın işleyişi, kadını ve erkeği toplumda ayrı yerlerde konumlandırmış, onları belli rollere tabi tutmuştur. Görevlerine sıkıca tutunan bireyler, ataerkil sistemle işbirliği halinde namusun sürekliliğini sağlamışlardır.

Namusun toplumdaki günlük pratiklere eklemlenmiş bir olgu olduğu gerçeği, namus ve dil ilişkisiyle gösterilmeye çalışılmış; bunun devlet aracılığıyla kurumsallaşan bir eyleme dönüşmesi sorgulanmıştır. Geleneklerle ilişkilendirilen namusun aslında zannedildiği gibi modern zamanlarda yok olmadığı ve olamayacağı bu anlamda oldukça açıktır.

“Namusun günümüzde hala kadının kontrolü üzerinden bir anlamı muhafaza etmesi, kadın ve erkeğin bu tanımı içselleştirmesinden kaynaklanır. Bunun nedeni ise, iktidarın her zaman bir güç uygulama zorunluluğu olmadan serbestçe bireyler arasında dolaşabilmesidir”. 


\section{KAYNAKÇA}

Abu-Odeh, L. (2003). "Arap Toplumlarında Namus Cinayetleri ve Toplumsal Cinsiyetin İnşası”. Müslüman Toplumlarda Kadın ve Cinsellik, 243-263. İstanbul: İletişim Yayınları.

Agacinski, S. (1998). Cinsiyetler Siyaseti. Çev. İsmail Yerguz. Ankara: Dost kitabevi.

Agamben, G. (2001). Kutsal İnsan Egemen İktidar ve Çıplak Hayat. Çev. İsmail Türkmen. İstanbul: Ayrıntı Yayınları.

Akal, C. B. (1994). Siyasi İktidarın Cinsiyeti. Ankara: İmge Kitabevi.

Altınay, A. (2004). The Myth of the Military Nation Militarism Gender and Education in Turkey. Palgrave-Macmilllan: United States of America.

Berktay, F. (2009). Feminist Teorinin Önemli Bir Alanı: Cinsellik. Cogito, 58, 58-72.

Blank, H. (2008). Bekaretin El Değmemiş Tarihi. Çev. Emek Ergün. İstanbul: İletişim Yayınları.

Caner, E. (2004). Kutsal Fahişeden Bakire Meryem'e Toprak ve Kadın. İstanbul: Su Yayınları.

Connell, R. W. (1998). Toplumsal Cinsiyet ve İktidar Toplum, Kişi ve Cinsel Politika. Çev. Cem Soydemir. İstanbul: Ayrıntı Yayınları.

De Beauvoir, S. (1993). Kadın. İstanbul: Payel Yayınları.

Decker, C. (1998). “A Broken Promise: The Continued Use of Virginity Control Examinations in Turkey”. Buffala Human Rights Law Review. 4, 317-40.

Eğilmez, E. (Yapımcı), \& Ökten, Z. (Yönetmen) (1977). Çöpçüler Kralı. İstanbul: Arzu Film.

Engels, F. (2008). Ailenin, Özel Mülkiyetin ve Devletin Kökeni. Çev. Kenan Somer. Ankara: Sol Yayınları.

Foucault, M. (1993). Cinselliğin Tarihi. Çev. Hülya Tufan. İstanbul: Afa Yayınları.

Göktürk, N. (2010). “5237 Sayılı Türk Ceza Kanunu ve Kadın” konulu seminer.

İlkkaracan, P. (der.). (2003). Müslüman Toplumlarda Kadın ve Cinsellik. Çev. Ebru Salman. İstanbul: İletişim Yayınları.

Kadının İnsan Hakları-Yeni Çözümler Derneği (2007). Türk Ceza Kanunu’nda Cinsel Haklarımız Var.

Kandiyoti, D. (1997). Cariyeler, Bacılar, Yurttaşlar. İstanbul: Metis Yayınları.

Karabaş, S. (1999). Bütüncül Türk Budunbilimine Doğru. İstanbul: YKY.

King, D. E. (2008). “The Personal is Patrilineal: Namus as Sovereignty”. Identities, 15 (3), 317-42.

Koğacıoğlu, D. (2007). “Gelenek Söylemleri ve İktidarın Doğallaşması: Namus Cinayetleri Örneği”, Kültür ve Siyasette Feminist Yaklaşımlar. 3, http://www.feministyaklasimlar.org .

Küçük, S. (2003). “Cinsiyet Ayrımlı Atasözlerinde Kadın ve Erkek Kimliği”. AKÜ, Sosyal Bilimler Enstitüsü Dergisi, cilt V, 2, 213-24.

Lei, X. (2006). "Sexism in Language”. Journal of Language and Linguistics. 1, 87-94.

Mernissi, F. (1987). Beyond the Veil Male Female Dynamics in Modern Muslim Society. Amerika Birleşik Devletleri: Indiana University Press.

Mernissi, F. (2003). “Bekaret ve Ataerki”. Müslüman Toplumlarda Kadın ve Cinsellik, 99-113. İstanbul: İletişim Yayınları.

Mernissi, F. (2003). “İslam’da Aktif Kadın Cinselliği Anlayıșı”. Müslüman Toplumlarda Kadın ve Cinsellik, 33-53. İstanbul: İletişim Yayınları.

Miakhel, S. (2009). "Understanding Afghanistan: The Importance of Tribal Culture and Structure in Security and Governance”. Asian Survey, Vol. 35 (7).

Millett, K. (1987). Cinsel Politika. Çev. Seçkin Selvi. İstanbul: Payel Yayınevi.

Mojab, S., \& Abdo, N. (der.), (2006). Namus Adına Şiddet Kuramsal ve Siyasal Yaklaşımlar. İstanbul: İstanbul Bilgi Üniversitesi Yayınları.

Motzki, H. "Nāmūs". Encyclopaedia of the Qur'ān. General Editor: Jane Dammen McAuliffe, Georgetown University, Washington DC. Brill Online, 2012. Reference. Akdeniz University. 08 November 2012. http://referenceworks.brillonline.com/entries/encyclopaedia-of-the-quran/namus-SIM_00297

Motzki, H. “Namus”. Encyclopaedia of the Qur'an. General Ed. Jane Dammen McAuliffe. Georgetown University, Washington DC. Brill Online, 2012. 
Mutluer, N. (der.), (2008). “Türkiye'de Cinsiyet Hallerinin Sınırları: Namussallaştırma”. Cinsiyet Halleri Türkiye’de Toplumsal Cinsiyetin Kesişim Sınırları, 14-30. İstanbul: Varlık Yayınları.

Nişanyan, S. (2009). Sözlerin Soyağacı Çağdaş Türkçe’nin Etimolojik Sözlüğü. İstanbul: Adam Yayıncılık.

Ökten, Ş. (2009). “Toplumsal Cinsiyet ve İktidar: Güneydoğu Anadolu Bölgesi’nin Toplumsal Cinsiyet Düzeni”. Uluslararası Sosyal Araştırmalar Dergisi (The Journal of International Social Research), 2 (8), 302-12.

Özyeğin, G. (2009). "Virginal Facades Sexual Freedom and Guilt among Young Turkish Women”. European Journal of Women's Studies, 16 (2), 103-23.

Parla, A. (2001). 'The “Honor' of the State: Virginity Examinations in Turkey'. Feminist Studies, 27, 65-88.

Pervizad, L. (2005). "An Interdisciplinary and a Holistic Attempt to Understand the Honor Killings in Turkey”. 10/148 Esas Numaralı Meclis Araştırması Önergesi.

Schemitt, C. (2003). The Nomos of The Earth in the International Law of the Jus Publicum Europaeum. New York: Telos pres publishing.

Shahmahmood, M. (2009). Understanding Afghanistan: The Importance of Tribal Culture and Structure in Security and Governance. http://www.pashtoonkhwa.com/files/books/Miakhel-ImportanceOfTribal StructuresInAfghanistan.pdf

Sirman N. (2006). Önsöz "Namusun Arka Planı”. “Haremler ve Kuzenler” 21-8, Yazan: Germaine Tillion, Çev. Şirin Tekeli, \& Nükhet Sirman. İstanbul: Metis Yayınları.

Sirman, N. (2006). “Akrabalık, Siyaset ve Sevgi: Sömürge Sonrası Koşullarda Namus- Türkiye Örneği”. Namus Adına Şiddet Kuramsal ve Siyasal Yaklaşımlar, 43-61. Yazanlar: Shahrzad Mojab ve Nahla Abdo, Çev. Güneş Kömürcüler. İstanbul: İstanbul Bilgi Üniversitesi Yayınları.

Tahincioğlu, N. (2011). Namusun Halleri. İstanbul: Positiga Yayınları.

Tillion, G. (2006). Harem ve Kuzenler. Çev. Nükhet Sirman, \& Şirin Tekeli. İstanbul: Metis Yayınları.

Yuval-Davis, N. (2007). Cinsiyet ve Millet. Çev. Ayşin Bektaş. İstanbul: İletişim Yayınları.

\section{İnternet Erişimleri}

http://www.bianet.org/bianet/kadin/140124-allaya-32-yil-sonra-burun-ameliyati , 6 Kasım 2012.

http://www.tudkad.org.tr/images/MedeniKanun.pdf, 8 Kasım 2012.

http://www.nisanyansozluk.com/?k=namus, 8 Kasım 2012.

http://www.tbmm.gov.tr/kanunlar/k5252.html, 9 Kasım 2012.

http://www.tdk.gov.tr, 13 Kasım 2010.

http://www.thefreedictionary.com/honest, 9 Kasım 2012. 